THE COLD WAR FROM THE MARGINS 



\section{THE COLD WAR FROM THE MARGINS}

A Small Socialist State on the Global Cultural Scene

THEODORA K. DRAgOSTINOVA 


\section{Copyright (C) 2021 by Theodora Dragostinova}

This book is freely available in an open access edition thanks to TOME (Toward an Open Monograph Ecosystem)-a collaboration of the Association of American Universities, the Association of University Presses, and the Association of Research Libraries_-and the generous support of The Ohio State University Libraries. Learn more at the TOME website, available at: openmonographs.org.

The text of this book is licensed under a Creative Commons Attribution-NonCommercial-NoDerivatives 4.0 International license: https: / / creativecommons.org/ licenses/by-nc-nd/4.0/. To use this book, or parts of this book, in any way not covered by the license, please contact Cornell University Press, Sage House, 512 East State Street, Ithaca, New York 14850. Visit our website at cornellpress.cornell.edu.

First published 2021 by Cornell University Press

Printed in the United States of America

\section{Library of Congress Cataloging-in-Publication Data}

Names: Dragostinova, Theodora, 1972- author.

Title: The Cold War from the margins : a small socialist state on the global cultural scene / Theodora K. Dragostinova.

Description: Ithaca [New York] : Cornell University Press, 2021. Includes bibliographical references and index.

Identifiers: LCCN 2020034764 (print) | LCCN 2020034765 (ebook) | ISBN 9781501755552 (paperback) | ISBN 9781501755569 (epub) | ISBN 9781501755576 (pdf)

Subjects: LCSH: Cultural diplomacy—Bulgaria—History20th century. | Cold War-Social aspects. | Politics and culture-Bulgaria-History-20th century. | BulgariaCultural policy—20th century.

Classification: LCC DR92 .D73 2021 (print) |

LCC DR92 (ebook) | DDC 949.903/1—dc23

LC record available at https:/ / lccn.loc.gov/ 2020034764

LC ebook record available at https: / / lccn.loc.gov/ 2020034765 
To my parents 
